\title{
PRESERVATIVE TREATMENT OF BAMBOO GULM FOR PRODUCING GREEN COLOUR AND ENHANGING FUNGAL DURABILITY
}

\author{
Oh JJ', ${ }^{1,2}$ Ra JB ${ }^{3} \&$ Kim $\mathrm{GH}^{1, *}$ \\ ${ }^{1}$ Division of Environmental Science E Ecological Engineering, College of Life Sciences $\mathcal{E}$ Biotechnology, Korea \\ University, 145, Anam-ro, Seongbuk-gu, Seoul 02841, Korea \\ ${ }^{2}$ Institute of Life Science and Natural Resources, Korea University, 145, Anam-ro, Seongbuk-gu, Seoul 02841, Korea \\ ${ }^{3}$ Department of Interior Materials Engineering, Gyeongsang National University, Jinju 52725, Korea \\ *lovewood@korea.ac.kr
}

Submitted January 2021; accepted March 2021

\begin{abstract}
This research was performed to investigate the feasibility of using copper-based wood preservative treatment for producing green colour on the bamboo surface and enhancing the fungal decay resistance of treated bamboo. Preliminary outdoor weathering tests were carried out to evaluate the green colour fastness of treated bamboo culms. In addition, fixation and leaching tests were also conducted to evaluate the safety of preservative-treated bamboo. A two-step treatment process was recommended to enhance bamboo green colour production, fungal decay resistance, production rate of treated bamboo and prevent sludge formation in treatment solution. In the treatment process, the bamboo was pressure-treated until refusal point with $4 \%$ chromated copper arsenate- 3 to achieve required preservative retention and dipped into $4 \%$ chromated copper arsenate- 3 for 2 days to produce green colour on the bamboo surface. The chromated copper arsenate-treated bamboo samples had outstanding colour fastness and mildew resistance after 24 months of outdoor weathering. The fixation and leaching tests demonstrated that the total amount of preservative components leached from the chromated copper arsenate-treated bamboo samples was high to raise safety issues and caused environmental problem during the use of treated bamboo in the field.
\end{abstract}

Keywords: Bamboo, chromated copper arsenate-3, green colour production, fungal decay resistance, colour fastness, safety

\section{INTRODUCTION}

The susceptibility of bamboo culm to fungus and insect attacks and the fading of its green colour over time was the major reason for bamboo products not to be preferred for exterior uses such as landscaping materials. The average service life of untreated bamboo was generally less than 3 years when it was used at ground-contact conditions (Liese 1980). Moreover, the attractive green colour of the bamboo epidermis gradually faded and discoloured into yellowish-brown and gray due to the deterioration of chlorophyll and weathering when exposed to ambient environments.

Various chemical treatments for green colour protection or conservation of bamboo were widely studied in Taiwan over the past decades (Chang \& Wu 2000a, Chang \& Wu 2000b, Chang \& Yeh 2000, Chang \& Yeh 2001, Chang et al. 2001, Chang et al. 2002,
Chung et al. 2005, Chung et al. 2008, Chung et al. 2009, Chung et al. 2011, Wu et al. 2002, $\mathrm{Wu}$ et al. 2004, Wu et al. 2005). However, no studies on preservation of bamboo against decay from soft-rot fungi and green colour protection were conducted, even though there were a few studies on mildew resistance of chemically-treated bamboo during indoor and outdoor exposure (Chung et al. 2008, Wu et al. 2002, Tang et al. 2012). Treatment with wood preservative was important to protect bamboo products from decay and soft-rot fungi. The preservative must be absorbed into the treated bamboo products to achieve the required retention for preventing the attack of decay and soft-rot fungi. Since the high moisture content in fresh bamboo restricted the amount of preservative that could be absorbed, dried bamboo should be used for providing adequate protection against fungal 
biodeterioration. Preservative treatment with copper-based preservatives offered a useful solution for the problems as the green colour would be produced on the surface of treated bamboo and enhanced fungal resistance after treatment. In the case of wood, the surface colour of treated wood with copper-based preservatives such as chromated copper arsenate, alkaline copper quat, copper azole and bis-(N-cyclohexyl-diazeniumdioxy)-copper were generally greenish and became darker with the increase of preservative retention.

This study was conducted to investigate the feasibility of using copper-based wood preservative treatment for both green colour production and bamboo preservation against fungal decay. An appropriate preservative including optimum preservative concentration for green colour production and decay resistance was selected and the proper treatment method was carefully chosen to consider mass production and to avoid sludge formation. Green colour fastness was evaluated through 24-month outdoor weathering and the safety of preservative-treated bamboo was also investigated through fixation and leaching tests.

\section{MATERIALS AND METHODS}

\section{Sample preparation}

Three-year-old giant timber bamboo (Phyllostachys bambusoides), hachiku bamboo (Phyllostachys nigra var. henosis) and moso bamboo (Phyllostachys pubescens) were obtained from the planted bamboo forest in the southern part of Korea. The fresh bamboo culms were cut into strips with dimensions of $50 \mathrm{~mm}$ (longitudinal) $\times 20 \mathrm{~mm}$ (tangential) $\times 5 \mathrm{~mm}$ (radial) for green colour production tests and cut into $20 \mathrm{~mm}$ (longitudinal) $\times$ $20 \mathrm{~mm}$ (tangential) $\times 5 \mathrm{~mm}$ (radial) samples for decay and fixation/leaching tests. All the samples were stored at $20{ }^{\circ} \mathrm{C}$ until their moisture content reached about $12 \%$.

\section{Pretreatment for wax removal}

The wax layer on bamboo culm was removed with the optimised treatment conditions determined in the previous study by $\mathrm{Ra}$ et al. (2020). Air-dried bamboo samples were treated with a mixture of $5 \%$ potassium hydroxide and $3.5 \%$ sodium dodecyl sulfate at $90{ }^{\circ} \mathrm{C}$ for 1 hour. The bamboo samples were immersed in distilled water for 24 hours to remove the residual chemicals and air-dried at room temperature until their moisture content reached about $12 \%$.

\section{Preservative treatments}

The air-dried bamboo samples were diptreated for 10 days and pressure-treated with $5 \%$ preservative solutions to investigate the effects of preservative types and treatment methods on green colour production. Four water-based copper-based wood preservatives such as chromated copper arsenate-3 (47.5\%

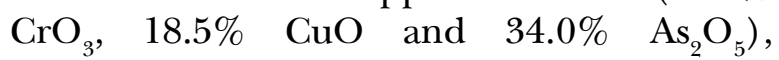
alkaline copper quat-2 $(66.7 \% \quad \mathrm{CuO}$ and $33.3 \%$ didecyldimethylammonium chloride), copper azole-1 $\left(49.0 \% \mathrm{CuO}, 49.0 \% \quad \mathrm{H}_{3} \mathrm{BO}_{3}\right.$ and $2.0 \%$ tebuconazole) and bis-(Ncyclohexyl-diazeniumdioxy)-copper-1 $\left(61.5 \% \mathrm{CuO}, 24.5 \% \mathrm{H}_{3} \mathrm{BO}_{3}\right.$, and $14.0 \%$ Bis(N-cyclohexyldiazeniumdioxy)-copper) were tested in this study. The pressure treatments were performed by the full-cell process where an initial vacuum of $760 \mathrm{mmHg}$ was applied for 30 minutes and the bamboo samples were later treated under the pressure of 14 $\mathrm{kg} \mathrm{cm}{ }^{-2}$ until reaching the refusal point. After the treatment, all specimens were allowed to drip for 10 minutes and conditioned without drying at $21^{\circ} \mathrm{C}$ for 2 weeks for appropriate fixation of metal components. The samples were then air-dried at room temperature for 2 weeks before measurement of surface colour.

\section{Colour measurements}

The surface colour of fresh and preservativetreated bamboo samples in the $\mathrm{L}^{*} \mathrm{a} * \mathrm{~b} *$ colour space was measured with a colourimeter. In the colour space, the chromaticity coordinate L* indicated lightness the value on the white/ black axis, $a^{*}$ indicated the value on the red/ green axis and $b^{*}$ indicated the value on the blue/yellow axis. The green colour of the bamboo surface was evaluated in terms of $a^{*}$ value. A positive $a^{*}$ value indicated the sample was red and a negative value was found for a green sample. Thus, a smaller value of $a^{*}$ indicated a greener sample. 


\section{Decay tests}

Among the four treatments, only chromated copper arsenate-3 dip treatment produced the green colour on the bamboo surface. Thus, decay tests were performed to determine the minimum treatment concentration of chromated copper arsenate-3 needed to prevent fungal attack by decay and soft-rot fungus. The samples for decay tests were pressure-treated with various concentrations of chromated copper arsenate-3 solutions by the full-cell process.

After the preservative treatment, the samples were allowed to drip for 10 minutes, conditioned without drying at $60{ }^{\circ} \mathrm{C}$ for 24 hours and then air-dried at room temperature for 2 weeks. The white-rot fungus Trametes versicolour and the soft-rot fungus Arthrinium phaeospermum were used for the decay test. The reason for selecting $T$. versicolour and A. phaeospermum as test fungus was their high isolating frequency from bamboo used outdoors in Korea and their decay capabilities (Kim et al. 2011). The decay tests for whiterot fungus were performed according to the Japanese Industrial Standard (JIS) K 1571 (JIS 2010) while the tests for soft-rot fungus were performed according to a vermiculite burial method (Nilsson 1973).

\section{Outdoor exposure test}

In the colour fastness study, air-dried bamboo samples with dimensions of $100 \mathrm{~mm}$ (longitudinal) $\times 50 \mathrm{~mm}$ (tangential) $\times 5 \mathrm{~mm}$ (radial) were pretreated for wax removal and followed by a two-step process in which the bamboo samples were first pressureimpregnated until refusal point with $4 \%$ chromated copper arsenate- 3 and then dipped into $4 \%$ chromated copper arsenate-3 for 2 days. After the preservative treatments, the samples were allowed to drip for 10 minutes, conditioned without drying at $21{ }^{\circ} \mathrm{C}$ for 2 weeks, and then air-dried at room temperature for 2 weeks. The treated bamboo samples were exposed outdoor for 24 months beginning from 1st May 2016 to 30th April 2018. The weathering rack was positioned facing south at an angle of $45^{\circ} \mathrm{C}$ to the ground in the campus of Korea University in Seoul, Korea. The surface colour of weathered chromated copper arsenate-treated bamboo samples in the $\mathrm{L}^{*} \mathrm{a} \mathrm{b}^{*}$ colour space was measured by using a colourimeter.

\section{Fixation and leaching tests}

Air-dried bamboo samples with dimensions of $20 \mathrm{~mm}$ (longitudinal) $\times 20 \mathrm{~mm}$ (tangential) $\times 5 \mathrm{~mm}$ (radial) were pretreated for wax removal and later treated by a two-step process consisting of the pressure impregnation of bamboo samples until reaching refusal point with $4 \%$ chromated copper arsenate- 3 followed by 2 days dipping into $4 \%$ chromated copper arsenate-3. The treated samples were immediately wrapped in aluminum foil and underwent fixation without drying at $21^{\circ} \mathrm{C}$ for different periods of time. The rates for fixation in the treated bamboo samples were evaluated using the expressate method (McNamara 1989). The expressed solutions were analysed for its hexavalent chromium content using the diphenylcarbazide colourimetric method (ASTM 2007). The rate of fixation at any given time was evaluated by comparing the hexavalent chromium concentration of the expressed solution with the initial treating solution.

The leaching tests were performed according to the AWPA standard E11-15 with some modifications (AWPA 2015a). After a 14day leaching period, the combined leachate samples from the nine sampling times were analysed using inductively coupled plasmaoptical emission spectrometry to determine their chromated copper arsenate components according to the procedure given in the AWPA standard A21-14 (AWPA, 2015b). The total leaching was expressed as the percent loss of each chromated copper arsenate component relative to the amount initially retained in the treated samples.

\section{RESULTS AND DISCUSSION}

\section{Selection of the preservative type and treatment method for green colour production}

The feasibility of using the wood preservative treatment for the production of green colour on the dried bamboo surface was evaluated by comparing the $a^{*}$ values of dip-treated and 
pressure-treated bamboo samples with 5\% solutions of chromated copper arsenate-3, alkaline copper quat-2, copper azole-1 and bis-(N-cyclohexyl-diazeniumdioxy)-copper-1 with those of fresh bamboo. The $\mathrm{a}^{*}$ values of bamboo samples dip-treated with alkaline copper quat-2, copper azole-1 and bis- $(\mathrm{N}$ cyclohexyl-diazeniumdioxy)-copper-1 showed positive values regardless of bamboo species, suggested that those preservatives had no effect on the production of green colour (Table 1). On the contrary, the giant timber bamboo, hachiku bamboo, and moso bamboo samples treated with chromated copper arsenate-3 had the $\mathrm{a}^{*}$ values of $-14.95,-16.70$ and -14.78 , respectively. The results indicated that chromated copper arsenate- 3 could be used for green colour production.

In the pressure treatment, no clear green colour could be produced on the bamboo surface for all the tested preservatives. The colour of the bamboo surface after the pressure treatment turned from greenish brown to light brown, which was different from the original colour of the fresh bamboo surface. A possible reason for result might be the pressure treatment could not provide sufficient time for the copper ions to adhere to the bamboo surface.

Dip treatments were performed by immersing the dried bamboo samples into each of $1 \%, 3 \%$ and $5 \%$ chromated copper arsenate-3 solutions for 3, 6, 12, 24, 48, 120 and 240 hours. The a* values decreased progressively with the increase of dipping time and a green colour similar to the fresh bamboo colour was developed on the treated bamboo surface after about 2 days of the dip treatment, except for the giant timber treated with $1 \%$ chromated copper arsenate-3 and moso bamboo treated with $1 \%$ chromated copper arsenate-3 (Figure 1). The $\mathrm{a}^{*}$ values of fresh hachiku bamboo were at -5.53 and could be achieved by the dip treatment with $1 \%$ chromated copper arsenate-3. However, the production of green colour similar to fresh giant timber bamboo and moso bamboo could not be achieved even after 10 days dip treatment with $1 \%$ chromated copper arsenate-3. In common practical application, a short treatment time that could produce colour was more desirable. Thus, dip treatment with $3 \%$ chromated copper arsenate-3 for 2 days was recommended to produce green colour on the dried bamboo surface even though the $a^{*}$ values of giant timber bamboo treated with $3 \%$ chromated copper arsenate-3 for 2 days were lower than that of fresh giant timber bamboo.

The chromated copper arsenate-3 treatment for producing green colour and simultaneously enhancied fungal durability can only be used in countries where the chromated copper arsenate usage was still applicable. Non-chromated copper arsenate preservatives such as alkaline copper quat

Table 1 The values of $\mathrm{L}^{*} \mathrm{a}^{*}$, and $\mathrm{b}^{*}$ of giant timber bamboo, hachiku bamboo and moso bamboo dip-treated with $5 \%$ copper-based wood preservatives for 10 days

\begin{tabular}{lccccccccc}
\hline \multirow{2}{*}{$\begin{array}{l}\text { Treatment } \\
\text { types }\end{array}$} & \multicolumn{3}{c}{ Giant timber bamboo } & \multicolumn{3}{c}{ Hachiku bamboo } & \multicolumn{3}{c}{ Moso bamboo } \\
\cline { 2 - 10 } & $\mathrm{L}^{*}$ & $\mathrm{a}^{*}$ & $\mathrm{~b}^{*}$ & $\mathrm{~L}^{*}$ & $\mathrm{a}^{*}$ & $\mathrm{~b}^{*}$ & $\mathrm{~L}^{*}$ & $\mathrm{a}^{*}$ & $\mathrm{~b}^{*}$ \\
\hline Untreated & 33.40 & -7.52 & 11.69 & 44.52 & -4.98 & 9.08 & 34.79 & -5.47 & 7.56 \\
bamboo & $(1.58)$ & $(0.71)$ & $(1.72)$ & $(4.99)$ & $(0.66)$ & $(1.80)$ & $(2.25)$ & $(1.04)$ & $(2.44)$ \\
& 52.60 & -14.95 & 21.22 & 50.37 & -16.70 & 17.83 & 48.90 & -14.78 & 20.29 \\
CCA-3 & $(0.61)$ & $(0.85)$ & $(1.30)$ & $(1.40)$ & $(0.39)$ & $(0.33)$ & $(0.53)$ & $(0.18)$ & $(0.50)$ \\
& 28.95 & 1.81 & 9.63 & 25.51 & 2.98 & 10.56 & 29.86 & 2.81 & 12.77 \\
ACQ-2 & $(3.12)$ & $(0.20)$ & $(3.49)$ & $(2.78)$ & $(0.80)$ & $(1.68)$ & $(4.10)$ & $(0.58)$ & $(3.66)$ \\
& 30.73 & 2.19 & 12.27 & 28.34 & 3.21 & 15.44 & 33.84 & 3.56 & 14.87 \\
CUAZ-1 & $(1.21)$ & $(0.44)$ & $(1.51)$ & $(1.64)$ & $(0.65)$ & $(2.01)$ & $(1.78)$ & $(0.43)$ & $(2.11)$ \\
& 36.83 & 3.09 & 17.17 & 37.20 & 3.27 & 17.37 & 35.83 & 3.57 & 15.98 \\
CuHDO-1 & $(0.66)$ & $(0.54)$ & $(0.90)$ & $(1.32)$ & $(0.65)$ & $(2.08)$ & $(0.78)$ & $(0.33)$ & $(2.00)$ \\
\hline
\end{tabular}

Values represented the mean of three replicates, values in a parenthesis represented standard deviation; CCA-3 = chromated copper arsenate-3, ACQ-2 = alkaline copper quat-2,

CUAZ-1 = copper azole-1, CuHDO-1 = bis-(N-cyclohexyl-diazeniumdioxy)-copper-1;

$\mathrm{L}^{*}=$ value on the white/black axis, $\mathrm{a}^{*}=$ value on the red/green axis, $\mathrm{b}^{*}=$ value on the blue/yellow axis 

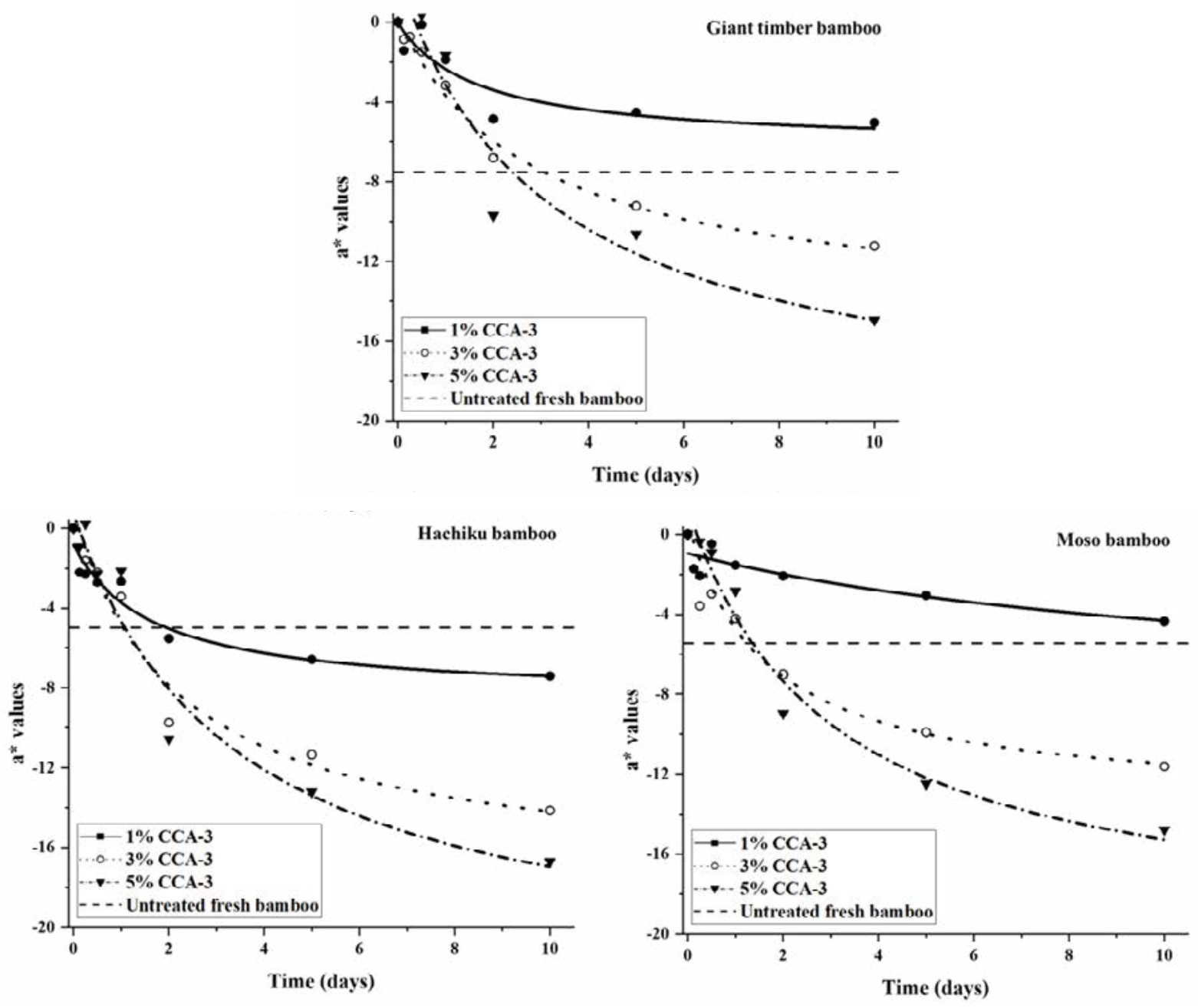

Figure 1 Changes of $\mathrm{a}^{*}$ values of the dip-treated dried bamboo samples with 1, 3 and $5 \%$ chromated copper arsenate-3 solutions for various dipping times

was applied for the same purposes to replace chromated copper arsenate because its use was banned in many countries due to human health and environmental safety concerns. Such usages of the non-chromated copper arsenate preservatives alone were not sufficient for green colour production as shown in Table 1. Thus, further investigation such as including green colourants as additives in those preservatives should be explored.

\section{Minimum chromated copper arsenate concentration for fungal decay resistance}

Decay tests were conducted to determine the minimum concentration of chromated copper arsenate-3 solution effective in preventing biological deterioration caused by decay and soft-rot fungus using the AWPA standard soil-block test. The mean percent mass lost of the chromated copper arsenate-treated bamboo samples at different concentration levels were shown in Figure 2. Based on the JIS K 1571 Standard, the preservative concentration which caused mass loss $3 \%$ after a 12-week fungal exposure was the minimum concentration for effective protection against fungal deterioration. The test results showed the minimum concentrations of chromated copper arsenate-3 solution required which prevented the attack of the T. versicolour and A. phaeospermum were $1.5 \%$ and $4.0 \%$ or equivalent to $6.60 \mathrm{~kg} \mathrm{~m}^{-3}$ and $17.60 \mathrm{~kg} \mathrm{~m}^{-3}$, respectively.

Therefore, the performance requirement of JIS K 1571 was fulfilled by pressure treatment with at least $4 \%$ chromated copper arsenate-3. The prevention against soft-rot 


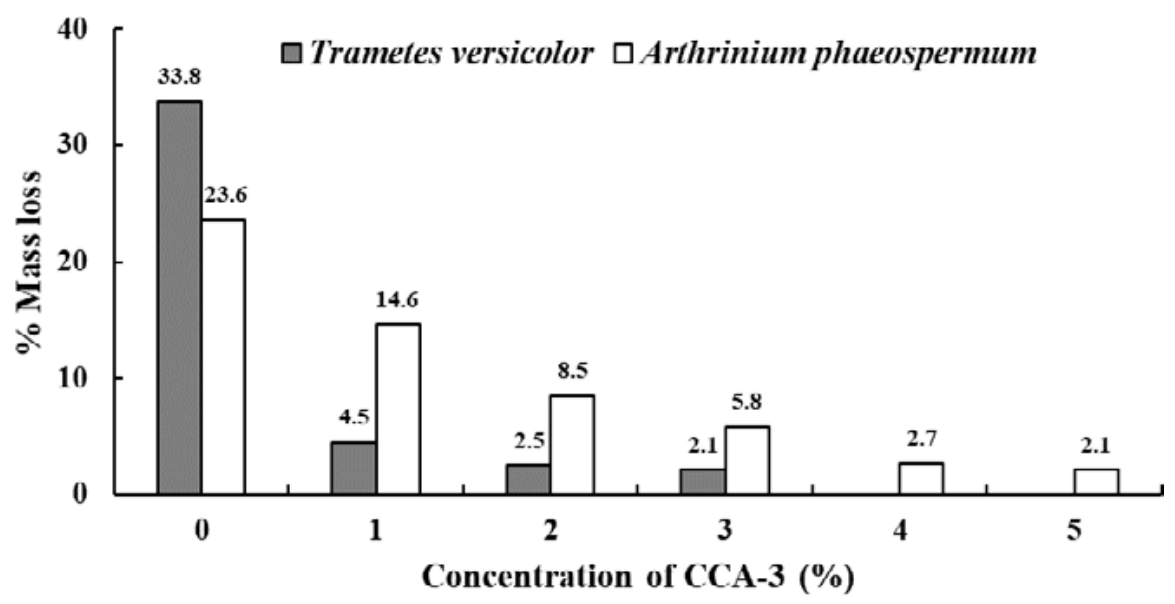

Figure 2 Effect of the concentration of chromated copper arsenate-3 on percent mass loss of treated bamboo against Trametes versicolour (white rot fungus) and Arthrinium phaeospermum (soft rot fungus)

fungi attack required higher retention of copper-containing preservatives (Daniel \& Nilsson 1988). Previous studies showed the preservative uptake of the bamboo samples was lower than expected at 55 to $60 \%$ (Lee et al. 2001) and bamboo material was relatively challenging to treat than wood material (Möller \& Mild 2019)

Treatment method on bamboo for green colour production and fungal resistant

Based on the above findings on the chromated copper arsenate-3 concentrations for green colour production and fungal decay resistance, bamboo samples should be treated with a $4 \%$ chromated copper arsenate-3 solution. Subsequently, green colour production could be achieved by a 2-day dip treatment with 3\% chromated copper arsenate-3 and two days dipping with $4 \%$ chromated copper arsenate-3 was enough to produce green colour on the bamboo surface. However, two days dipping in $4 \%$ chromated copper arsenate-3 was impossible to achieve preservative retention in the bamboo necessary for fungal decay resistance. Therefore, an additional study was conducted to determine the optimal dipping time to achieve the same uptake of chromated copper arsenate-3 with pressure treatment until refusal point at $55.1 \%$ for giant timber bamboo, $60.8 \%$ for hachiku bamboo and $59.5 \%$ for moso bamboo. The result showed 15 days dipping in $4 \%$ chromated copper

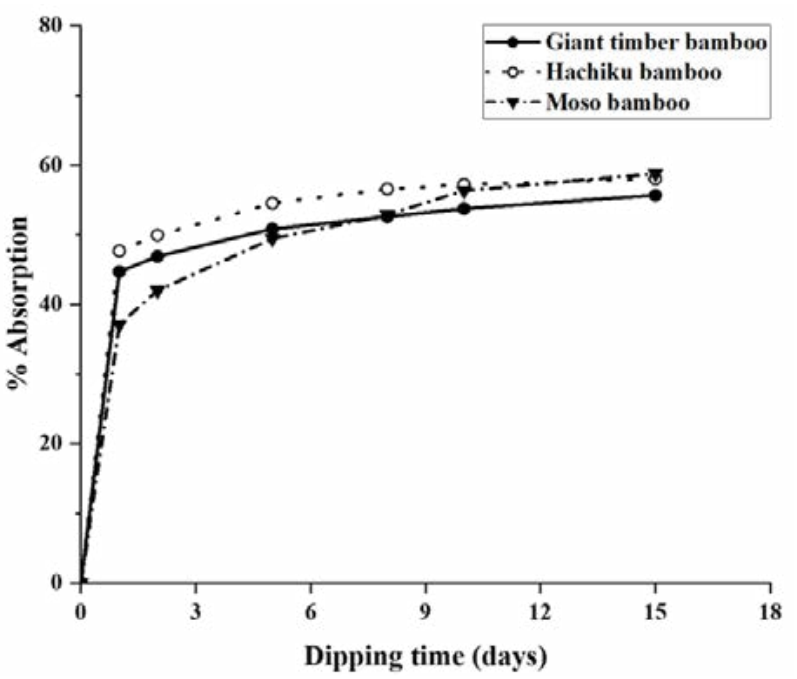

Figure 3 Changes of chromated copper arsenate-3 absorption of dip-treated bamboo samples according to dipping time

arsenate-3 solution was required (Figure 3).

Dipping treatment for 15 days resulted in $a^{*}$ values higher than those of fresh bamboo, indicating that 15 days was enough to produce green colour (Table 2). However, such dipping treatment was not suitable for mass production of sludge-free treated bamboo because of longer dipping time and insoluble sludge formation. The additional study demonstrated that pale green sludges were formed after 3-5 days of dip treatment. The sludge was caused by the reaction of starches in bamboo and the remaining potassium hydroxide in bamboo after the wax layer removing process with chromated copper arsenate components. 
Table 2 Changes in a* values of bamboo samples after dip treatment for 15 days and two-step treatment

\begin{tabular}{llll}
\hline Bamboo species & Untreated bamboo & Dip-treated bamboo & $\begin{array}{l}\text { Pressure treated and then } \\
\text { dip-treated bamboo }\end{array}$ \\
\hline Giant timber bamboo & $-7.52(0.71)$ & $-11.07(1.61)$ & $-6.75(0.35)$ \\
Hachiku bamboo & $-4.98(0.66)$ & $9.53(1.51)$ & $-5.69(0.97)$ \\
Moso bamboo & $-5.47(1.04)$ & $11.81(0.39)$ & $-6.87(0.82)$ \\
\hline
\end{tabular}

Values represented the mean of three replicates, values in parenthesis represented standard deviation

Therefore, a two-step treatment process was recommended to shorten the treatment time and to prevent sludge. Bamboo was pressure saturated until refusal point with chromated copper arsenate-3 to achieve required preservative retention and then dipped into preservative solution to produce green colour on the bamboo surface. As the result of further experiments, the chromated copper arsenate absorption reached $60 \%$ and green colour was produced on the bamboo surface after the pressure-treated bamboo samples were immersed in $4 \%$ chromated copper arsenate-3 for 2 days. There was no significant difference in the $\mathrm{a}^{*}$ values between pressuretreated and 2-days dipped bamboo and fresh bamboo (Table 2).

\section{Green colour fastness of chromated copper arsenate-treated bamboo}

Variations in the $\mathrm{a}^{*}$ values of the bamboo samples during outdoor weathering for 24

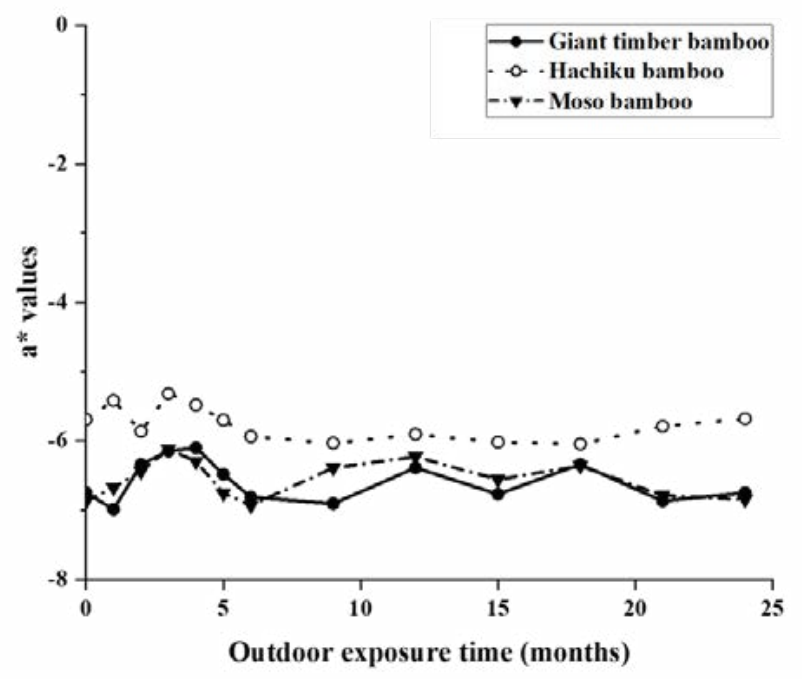

Figure 4 Changes in $a^{*}$ values of three bamboo species after outdoor exposure for 24 months months were shown in Figure 4 . The $\mathrm{a}^{*}$ values of all the bamboo species remained relatively the same, which showed that the green colour of the chromated copper arsenate-treated bamboo samples was maintained close to fresh bamboo samples after the 24-month exposure to outdoor environment. In addition, no evidence of fungal decay and mold growth on the sample surface.

\section{Safety of chromated copper arsenate- treated bamboo}

There was a slight difference in chromium reduction between the bamboo species but the fixation time of all chromated copper arsenatetreated bamboo samples was for 12 days (Figure 5 ). The fixation time for chromated copper arsenate in treated bamboo was shorter than the previously known time in treated wood. The amount of chromated copper arsenate components fixed in treated bamboo was lower than treated wood due to low absorption rate

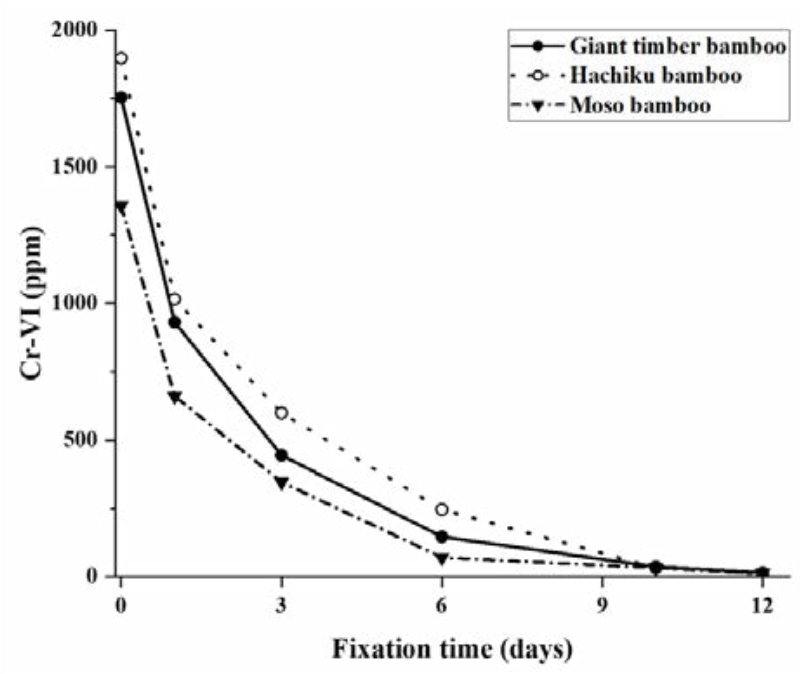

Figure 5 Comparison of fixation characteristics among three bamboo species during non-drying fixation at $21^{\circ} \mathrm{C}$ 
Table 3 The degree of chromated copper arsenate components leached from fully fixed chromated copper arsenate-treated bamboo

\begin{tabular}{lccc}
\hline \multirow{2}{*}{ Bamboo species } & \multicolumn{3}{c}{ Total amount of chromated copper arsenate components in leachate $(\mathrm{ppm})$} \\
\cline { 2 - 4 } & Chromium & Copper & Arsenic \\
\hline Giant timber bamboo & 0.04 & 0.12 & 0.21 \\
Hachiku bamboo & 0.03 & 0.09 & 0.22 \\
Moso bamboo & 0.04 & 0.11 & 0.19 \\
\hline
\end{tabular}

of bamboo.

The total amount of chromium, copper and arsenic components leached from the chromated copper arsenate-treated bamboo samples after the appropriate fixation time of 12 days were shown in Table 3 . No significant difference in leaching amount was observed between the bamboo species and the amount was not high to raise public concern about the risk of environmental pollution and hazard to human health. The cumulative leaching amount of chromated copper arsenate components was in the order of arsenic > copper $>$ chromium and the same trend was observed in chromated copper arsenate treated wood.

\section{CONGLUSIONS}

Dip treatment for dried bamboo culm with $3 \%$ chromated copper arsenate- 3 at ambient temperature for 2 days produced green colour regardless of bamboo species. Decay tests showed that at least $4 \%$ chromated copper arsenate-3 should be used for the pressure treatment to obtain enough retention for protection against fungal decay attack. Based on the findings, dried bamboo culm should be treated with $4 \%$ chromated copper arsenate-3 solution for the green colour production and fungal resistant. A two-step treatment process in which bamboo samples were pressure treated until refusal point with $4 \%$ chromated copper arsenate-3 to achieve required preservative retention and then dipped into $4 \%$ chromated copper arsenate-3 for 2 days to produce green colour on the bamboo surface was recommended. The recommendation managed to reduce the 15 days dip treatment and helped in the mass production of sludgefree chromated copper arsenate-treated bamboo. The chromated copper arsenate- treated samples exhibited excellent green colour fastness, resistance to fungal decay and discolouration after 24-month exposure to outdoor weathering. The leaching amount of preservative components from chromated copper arsenate-treated bamboo were not high to raise potential public health and ecological risks after the complete fixation of treated bamboo.

\section{AGKNOWLEDGEMENT}

This study was conducted with the support of Technology Development Program for Agriculture and Forestry and the Forest Science \& Technology Projects (Project No. S121010L110000) provided by the Korea Forest Service.

\section{REFERENGES}

Astm (American Society for Testing and Materials). 2007. ASTM D1687-02. Standards Test Methods for Chromium in Water. ASTM, West Conshohocken.

AwPa (American Wood Preservers' Association). 2015a. AWPA E11-15. Standard Method for Accelerated Evaluation of Preservative Leaching. AWPA, Birmingham, U.S.A.

AwPa (American Wood Preservers' Association). 2015b. AWPA A21-14. Standard Method for the Analysis of Wood and Wood Treating Solutions by Inductively Coupled Plasma Emission Spectrometry. AWPA, Birmingham, U.S.A.

Chang ST \& WU JH. 2000a. Green colour conservation of ma bamboo (Dendrocalamus latiflorus) treated with chromium-based reagents. Journal of Wood Science 46: 40-44. https://doi.org/10.1007/BF00779551

Chang ST \& WU JH. 2000b. Stabilizing effect of chromated salt treatment on the green colour of ma bamboo (Dendrocalamus latiflorus). Holzforschung 54: 327330. https://doi.org/10.1515/HF.2000.055

CHANG ST \& YEH TF. 2000. Effect of alkali pretreatment on surface properties and green colour conservation of moso bamboo (Phyllostachys pubescens Mazel). Holzforschung 54: 487-491. https://doi. org/10.1515/HF.2000.082 
Chang ST \& Yeh TF. 2001. Protection and fastness of green colour of moso bamboo (Phyllostachys pubescens Mazel) treated with chromium-based reagents. Journal of Wood Science 47: 228-232. https://doi.org/10.1007/BF01171226

Chang ST, Yeh TF \& Wu JH. 2001. Mechanisms for the surface colour protection of bamboo treated with chromated phosphate. Polymer Degradation and Stability 74: 551-557. https://doi.org/10.1016/ S0141-3910(01)00192-6

Chang ST, Wu JH \& YeH TF. 2002. Effects of chromatedphosphate treatment process on the green colour protection of ma bamboo (Dendrocalamus latiflorus). Journal of Wood Science 48: 227-231. https://doi. org/10.1007/BF00771372

Chung MJ, Wu JH \& Chang ST. 2005. Green colour protection of makino bamboo (Phyllostachys makinoi) treated with ammoniacal copper quaternary and copper azole preservatives. Polymer Degradation and Stability 90: 167-172. https://doi. org/10.1016/j.polymdegradstab.2005.03.005

Chung MJ, Cheng SS \& Chang ST. 2008. Environmentalbenign methods for the colour protection of stripe long-shoot bamboo (Bambusa dolichoclada) culms. Building and Environment 43: 745-750. https://doi. org/10.1016/j.buildenv.2007.01.014

Chung MJ, Cheng SS \& Chang ST. 2009. Environmentally benign methods for producing green culms of ma bamboo (Dendrocalamus latiflorus) and moso bamboo (Phyllostachys pubescens). Journal of Wood Science 55: 197-202. https://doi.org/10.1007/ s10086-008-1014-0

Chung MJ, Cheng SS, Lee CJ Et al. 2011. Novel environmentally benign methods for green-colour protection of bamboo culms and leaves. Polymer Degradation and Stability 96: 541-546. https://doi. org/10.1016/j.polymdegradstab.2011.01.008

DANIEL GF \& NiLSSONT. 1988. Studies on preservative tolerant Phialophora species. International Biodeterioration 24: 327-335. https://doi.org/10.1016/02653036(88)90018-8

KIM JJ, LeE SS, RA JB eT AL. 2011. Fungi associated with bamboo and their decay capabilities. Holzforschung 65: 271-275. https://doi.org/10.1515/hf.2011.004

Jis (Japanese Industrial Standard). 2010. JIS K 1571. Test methods for determining the effectiveness of wood preservatives and their performance requirements. JIS. Tokyo.

Lee AWC, Chen D \& Tainter FH. 2001. Comparative treatability of Moso bamboo and Southern pine with CCA preservative using a commercial schedule. Bioresource Technology 77: 87-88. https:// doi.org/10.1016/S0960-8524(00)00145-0

Liese W. 1980. Preservation of bamboos. Pp 165-172 in: Lessard, G. \& Chouinard, A. (eds) Bamboo Research in Asia. IDRC, Ottawa.

MCNAMARA WS. 1989. CCA Fixation Experiments-Part 1. IRG/WP 89-3504. The International Research Group on Wood Protection, Stockholm.

Möller R \& Mild G. 2019. Protection of Moso bamboo (Phyllostachys pubescens) materials against fungal decay and discolouration by treatment with wood preservatives. European Journal of Wood and Wood Products 77: 139-145. https://doi.org/10.1007/ s00107-018-1371-3

NiLsson T. 1973. Studies on wood degradation and cellulolytic activity of microfungi. Studia Forestalia Suecica. 104: 5-40.

RA JB, OH JJ \& Kıм GH. 2020. Optimization of alkali pretreatment conditions for wax removal from bamboo culm. Bioresources 15: 8202-8211. https:/ / doi.org/10.15376/biores.15.4.8202-8211

TANG TKH, Schmidt O \& Liese W. 2012. Protection of bamboo against mould using environment-friendly chemicals. Journal of Tropical Forest Science. 24: 285290. http://www.jstor.org/stable/23617085

Wu JH, Wu SY, Hsieh TH et AL. 2002. Effects of copper phosphorous salt treatment on green colour protection and fastness of ma bamboo (Dendrocalamus latiflorus). PolymerDegradation and Stability 78: 379-384. https://doi.org/10.1016/S0141-3910(02)00190-8

Wu JH, Chung MJ \& Chang ST. 2004. Evaluation of the effectiveness of alcohol-borne reagents on the green colour protection of makino bamboo (Phyllostachys makinoi). Polymer Degradation and Stability 83: 473-479. https://doi.org/10.1016/j. polymdegradstab.2003.08.014

Wu JH, Chung MJ \& Chang ST. 2005. Green colour protection of bamboo culms using one-step alkalipretreatment-free process. Journal of Wood Science 51: 622-627. https://doi.org/10.1007/s10086-0050698-7 